\title{
Densitas dan Morfologi Stomata Daun Pterocarpus indicus di Jalan Arif Rahman Hakim dan Kampus ITS, Surabaya \\ Dhimas Wildan Humami ${ }^{1)}$, Puput Anggie Widhiarti Sujono ${ }^{1^{*}}$, Iska Desmawati ${ }^{1)}$ \\ ${ }^{1)}$ Departemen Biologi, Institut Teknologi Sepuluh Nopember \\ *puput.anggie@gmail.com \\ DOI: https://doi.org/10.21107/rekayasa.v13i3.7869
}

\begin{abstract}
The relationship between physiological and environmental factors can affect the anatomical structure and morphology of stomata as organs that important to exchange carbon gas, oxygen, and water vapor as well as organs that are directly exposed to polluted environments that can inhibit the photosynthesis process of plant leaves. The purpose of this study was to determine differences in stomata density and morphology of Pterocarpus indicus leaves at locations suspected of having high pollution exposure and low pollution exposure. This study uses the leaf of Pterocarpus indicus as a type of plant that is often exposed to pollution. The leaf sampling method was carried out with 3 replications in the area of Arif Rahman Hakim Street and Taman Benzena, ITS Surabaya as a comparison of areas estimated to have high and low pollution exposure. Sampling using the abaxial side of the leaf by using the imprint method. Calculation of density is done by unit $\mathrm{mm}^{2}$ of leaf area under normal, closed, and abnormal stomata morphological conditions. The results obtained from the observation of stomata density in Taman ITS Benzena Surabaya are 32,502 stomata/mm² were opened, 65,004 stomata/ $\mathrm{mm}^{2}$ closed, and 13,630 stomata/ $\mathrm{mm}^{2}$ abnormal, while in the area of Arif Rahman Hakim Street, Sukolilo, Surabaya as a sample location assuming the pollution is 46,132 stomata/mm² were opened, 78,634 stomata $/ \mathrm{mm}^{2}$ closed and 13,630 stomata/ $\mathrm{mm}^{2}$ abnormal.
\end{abstract}

Keywords: abnormal, density, morphology, pollution, stomata

\section{PENDAHULUAN}

Ekofisiologi pohon adalah salah satu bidang keilmuan yang dapat membantu memberikan penjelasan atau analisis mengenai pertumbuhan suatu jenis pohon atau beberapa jenis pohon yang dipengaruhi oleh faktor lingkungan atau ekologis dan adanya keterlibatan proses fisiologis tumbuhan tersebut sebagai bentuk adaptasinya (Pearcy et al., 1989). Kesesuaian antara faktor fisiologis dan lingkungan yang dapat mempengaruhi pertumbuhan tanaman akan dapat terlihat melalui data atau keterangan yang didapatkan dari ekofisiologi ini (Paembonan, 2002). Kadar air, intensitas cahaya, konsentrasi $\mathrm{CO} 2$ dan suhu lingkungan merupakan faktor-faktor yang dapat mempengaruhi struktur fisiologi atau anatomi daun sebagai bentuk respon atau adaptasi selama pekembangan daun tumbuhan yang

\section{Article History:}

Received: Juli, 13 ${ }^{\text {th }}$ 2020; Accepted: Dec, $9^{\text {th }} 2020$.

Rekayasa ISSN: 2502-5325 has been Accredited by Ristekdikti (Arjuna) Decree: No. 23/E/KPT/2019 August 8th, 2019 effective until 2023 berperan penting untuk fotosintesis (Kim et al., 2014). Beberapa macam kerusakan struktur sel tertentu atau struktur anatomi pada daun tanaman, terutama sel yang berperan penting pada proses fotosintesis merupakan hasil respon fisiologi-ekologi tumbuhan (Rindyastuti \& Hapsari, 2017).

Stomata merupakan porus atau lubang dengan celah kecil berbentuk oval atau lonjong yang diapit 2 sel epidermis khusus, disebut sebagai sel penutup atau apertur untuk mengatur ukuran celah stomata, merupakan organ tumbuhan yang berfungsi sebagai lubang pertukaran gas yang terapar lagsung dengan gas karbon, oksigen dan uap air (Ingeswari, 2016). Posisisnya yang terpapar secara langsung dengan lingkungan dapat menjadi indikator

\section{Cite this as:}

Humami, D.W., Sujono, P.A.W \& Desmawati, I. (2020). Densitas dan Morfologi Daun Pterocarpus indicus di Jalan Arif Rahman Hakim dan Kampus ITS Surabaya. Rekayasa, 13 (3), 240-245. doi: https://doi.org/10.21107/rekayasa.v13i3.7869

(C) 2020 Dhimas Wildan Humami, Puput Anggie Widhiarti Sujono, Iska Desmawati 
faktor fisik yang berpengaruh terhadap tumbuhan dan anatominya.

Kondisi abnormal yang terjadi pada stomata berupa bentuk yang tidak simetris, mulut stomata yang tersumbat, sel penjaga mengkerut atau menghitam dan bentuk tak wajar lainnya dipengaruhi oleh paparan gas karbon dioksida, karbon monoksida, timbal serta polutan lain yang akan menyebabkan proses pertukaran gas dari daun ke lingkungan dan sebaliknya menjadi terhambat, pecahnya dinding sel penjaga (Pressel et al., 2014). Bebeberpa jenis tumbuhan memiliki kemapuan penyerapan gas karbon yang sangat baik, pada pohon Pterocarpus indicus memiliki kemampuan menyerap timbal $(\mathrm{Pb})$ yang besar dari akumulasi hasil sisa pembakaran kendaraan bermotor di sepanjang jalan raya, intensitasnya dapat menjadi sangat tinggi ketika melihat perbedaan usia daun (Yudha et al., 2013). Oleh karena itu dilakukan penelitian dengan tujuan untuk mengetahui perbedaan densitas dan morfologi stomata pada daun Pterocarpus indicus pada dua lokasi berbeda yang diduga memiliki paparan polusi tinggi dan paparan polusi rendah.

\section{METODE PENELITIAN}

\section{Penentuan lokasi}

Pengambilan sampel dilakukan pada 9 Maret 2019 dipagi hari, antara pukul 06.00-08.00 WIB pada 2 lokasi yang berbeda yaitu di Taman Benzena Departemen Kimia ITS (07²1 $01.4^{\prime \prime S}$; $\left.112^{\circ} 47^{\prime} 41.9^{\prime \prime E}\right)$ dan Jalan Raya Arif Rahman Hakim (07²1'22.5"S; $\left.112^{\circ} 46^{\prime} 58.5^{\prime \prime E}\right)$. Sampel daun yang dipilih adalah daun Pterocarpus indicus di bagian ujung ranting. Sampel kemudian dibawa ke Laboratorium Ekologi Departemen Biologi, Institut Teknologi Sepuluh Nopember, Surabaya untuk dilakukan pengamatan pada hari yang sama.

\section{Alat dan Bahan \\ Alat yang digunakan pada penelitian ini yaitu gunting, GPS (Global Positioning System), kaca objek, kaca penutup, mikroskop compound, kamera, dan alat tulis. Bahan berupa sampel daun Pterocarpus indicusdiamati dengan metode cetak atau imprint menggunakan pewarna kuku (Kuteks) dan selotip.}

\section{Cara Kerja}

Sampel diambil tanpa mencabut daun dari ranting, bagian abaksial daun kemudian dibersihkan dengan tisu, kemudian sampel daun dibuat preparat dengan mengoles permukaan abaksial daun dengan cat kuku bening Revlon ${ }^{\circledR}$ yang dibiarkan sedikit mengering kemudian diberi selotip, dibiarkan beberapa saat lalu ditarik lepas untuk mendapatkan cetakan stomata. Pengambilan sampel daun menggunakan cat kuku bening Revlon $₫$ bertujuan untuk membuat tiruan epidermis daun dan memantau perubahan ukuran stomatanya. Kuteks transparan dapat memberikan apusan epidermis yang jelas, stabil, dan hampir permanen untuk perbesaran stomata (Wu \& Zhao, 2017).

Pengamatan preparat stomata dilakukan menggunakan perbesaran 400x dengan luas bidang pandang $0.025 \mathrm{~mm}^{2}$. Pada saat pengamatan dalam bidang pandang, dihitung jumlah stomata dengan morfologi normal terbuka, normal tertutup dan abnormal pada 2 jenis sampel dari tiap lokasi untuk menghitung densitas stomata.Penghitungan densitas stomata dilakukan pada tiap kondisi morfologi stomata menggunakan rumus (Lestari, 2006) :

Densitas Stomata $=\frac{\text { Jumlah Stomata }}{\text { Luas Bidang pandang }}$

\section{HASIL DAN PEMBAHASAN \\ Tipe Stomata}

Stomata memiliki jenis atau tipe yang sangat beragam karena jenisnya dilihat dari hubungan posisi atau letak porus dan sel penjaga dengan posisi sel tetangga. klasifikasinya berbeda dengan klasifikasi bentuk stomata berdasarkan perkembangannya. Struktur dan tata letak posisi sel stomata dapat digunakan untuk studi taksonomi, meskipun tidak memungkiri bahwa dapat terjadi kemungkinan perbedaan tipe stomata pada familia, atau bahkan pada spesies tanaman yang sama (Haryanti, 2010).

Pterocarpus indicus atau Pohon Angsana merupakan jenis pohon meranggas dari Suku Papilionaceae yang memiliki tinggi hingga 25-35 m. Pohon Angsana terdistribusi mulai dari Asia Tenggara, Asia Timur, meluas ke arah timur, utara dan selatan kawasan Pasifik. Pohon Angsana mendiami kawasan tropis dan sub tropis dengan suhu antara $22-32^{\circ} \mathrm{C}$, namun tumbuh optimal pada iklim tropis di dataran tinggi. Tanaman ini 
dapat tumbuh subur dengan jenis tanah aluvial berlempung dengan nilai $\mathrm{pH}$ tanah yang asam hingga basa menengah (Danarto, 2013). Pterocarpus indicus memiliki tipe stomata tipe parasitik dicirikan dengan sel penjaga yang berfusi dengan satu atau lebih sel tetangga, memiliki sumbu membujur sejajar dengan sumbu sel tetangga dan apertur, umunya jenis stomata ini ditemukan pada familia Rubiaceae serta Magnoliaceae (Haryanti, 2010).

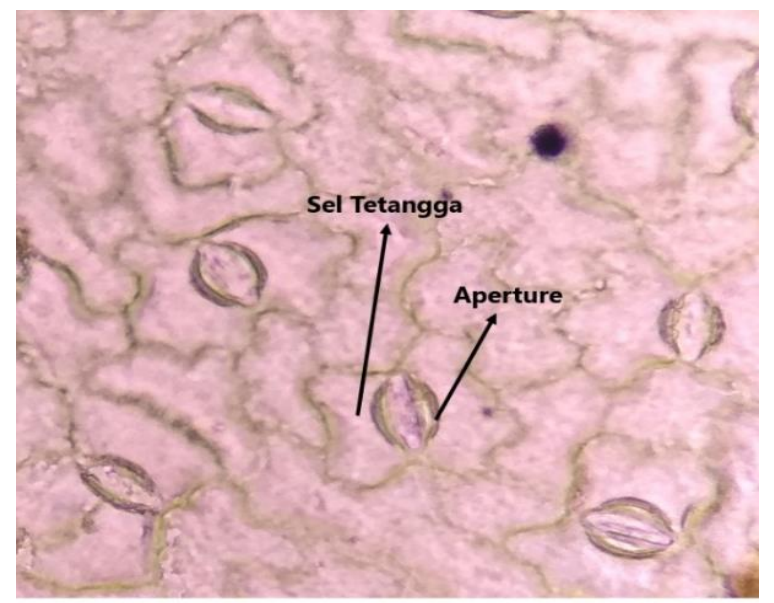

Gambar 1. Tipe Stomata Parasitik pada Sampel Daun Pterocarpus indicus

\section{Morfologi Stomata}

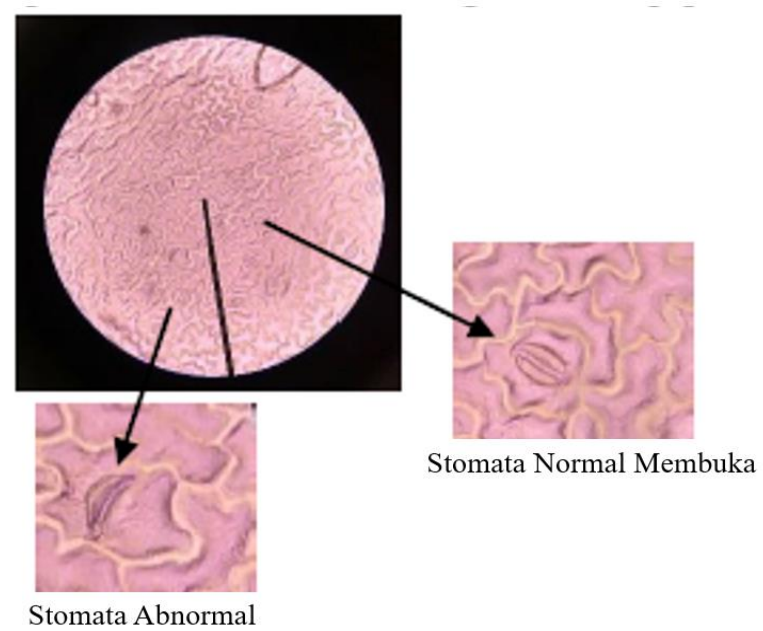

Gambar 2. Kondisi stomata pada Jalan Arif Rahman Hakim, Surabaya

Hasil pengamatan sampel daun Pterocarpus indicus di Jalan Raya Arif Rahman Hakim, Surabayadengan menggunakan mikroskop (pada Gambar 2) didapatkan bentuk morfologi stomata yang normal membuka dan bentuk stomata yang abnormal. Bentuk morfologi stomata normal membuka ditunjukkan dengan adanya celah lebar yang diapit oleh dua sel penutup yang bentuknya simetris. Diameter stomata menjadi lebar pada saat membuka karena adanya sel penutup yang membengkak dan berada dalam kondisi turgid akibat menyerap air melalui osmosis (Haryanti \& Meirina, 2009),

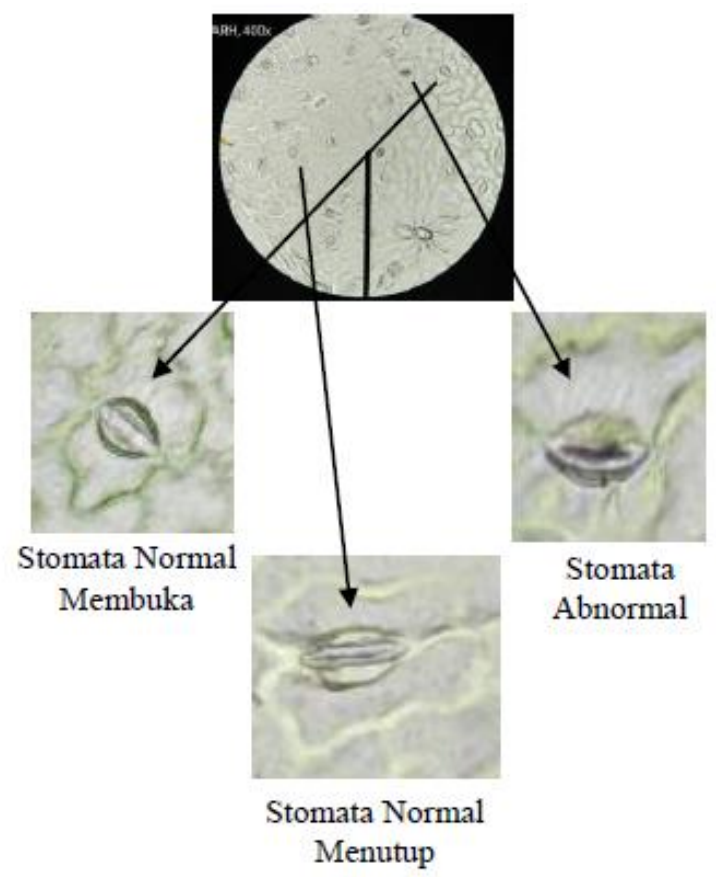

Gambar 3. Kondisi Stomata pada Daun Pterocarpus indicusdi Taman Benzena, ITS

Sedangkan pada pengamatan stomata daun Pterocarpus indicusdi Taman Benzena, ITS menunjukan morfologi stomata normal membuka, normal menutup dan stomata abnormal.Regulasi yang terjadi pada saat stomata saluran membuka meliputi $\mathrm{H}^{+}$ATPase memompa $\mathrm{H}^{+}$dari sel penutup kemudian terjadi hiperpolarisasi pada membran yang akan mengktivasi $\mathrm{K}^{+}$kedalam saluran (KAT1, KAT2, AKT1). Malate(2-) yang berasal dari pemecahan zat pati dan ion $\mathrm{NO}^{-}$dan $\mathrm{Cl}^{-}$yang ditransportasikan berkontribusi terhadap penumpukan zat terlarut intraseluler yang akan digunakan sebagai zat perantara impor gula yang digunakan untuk sintesis gula. Ion-ion akan menghasilkan tekanan turgor yang dibutuhkan agar stomata tetap membuka (DaszkowskaGolec \& Szarejko, 2013).

Kondisi morfologi stomata normal menutup ditandai dengan tidak adanya celah diantara dua sel penutup sehingga tidak nampak adanya cahaya yang melewati stomata ketika diamati dengan mikroskop. Stomata menutup karena sel 
penutup tidak lagi membengkak dan kembali berukuran normal karena kehilangan turgiditasnya (Haryanti \& Meirina, 2009). Regulasi yang terjadi ketika stomata menutup adalah $\mathrm{H}^{+}$ATPase dihambat, kemudian membran anion tipe-S dan tipe- $R$ diaktifkan. Ketika membran plasma mengalami depolarisasi, saluran tipe-S dan tipe- $R$ memfasilitasi penghabisan sel penutup beserta air yang ditransportasikan melalui aquaporin malate(2-), $\mathrm{Cl}^{-}$, dan NO3-. Di saat yang sama, $\mathrm{K}^{+}$memperbaiki saluran dari luar seperti GORK yang diaktifkan melalui depolarisasi malate(2-) yang kemudian menyebabkan penghabisan $\mathrm{K}^{+}$. Kenaikan konsentrasi $\mathrm{Ca}^{+}$akibat dari pelepasan $\mathrm{Ca}^{+}$ melalui saluran terjadi pada membran plasma dan di tonoplas menyebabkan terjadinya penutupan stomata (Daszkowska-Golec \& Szarejko, 2013).

Bentuk stomata yang abnormal ditandai dengan adanya morfologi sel penyusun stomata yang tidak seperti seharusnya. Hal ini tampak pada hasil pengamatan sampel stomata menggunakan mikroskop yang memperlihatkan adanya bentuk sel aparture yang tidak simetris dan terlihat mengalami kerusakan jaringan. Beberapa bentuk stomata yang abnormal memiliki jumlah sel penutup tunggal. Stomata yang abnormal terkadang tidak memiliki sel penutup, adanya perkembangan stomata yang terhenti, ataupun adanya koneksi sitoplasma antara satu stomata dengan stomata yang lain, dapat juga terjadi koneksi antara suatu stomata dengan sel epidermis (Delnavaz Hashemloian, 2014). Adanya gangguan pada stomata terjadi akibat pencemaran udara (polusi) oleh zat $\mathrm{SO}_{2}$ dan $\mathrm{O}_{3}$ dapat menimbulkan kerusakan fisik pada sel-sel epidermis di sekitar stomata yang terlihat dengan adanya sel-sel epidermis yang kolaps ketika diamati dengan mikroskop. Hal ini tidak hanya mempengaruhi kondisi fisik stomata, tetapi juga berpengaruh terhadap mekanisme fisologis sel untuk membuka dan menutup stomata (Mansfield, 1998).

\section{Densitas Stomata}

Densitas stomata adalah jumlah stomata pada suatu tanaman (Sihotang, 2017). Hasil pengamatan densitas stomata tumbuhan angsana (Pterocarpus indicus) pada Tabel 1.
Tabel 1. Hasil Penghitungan Densitas Stomata

\begin{tabular}{cccc}
\hline \multirow{2}{*}{ Lokasi } & \multicolumn{3}{c}{ Densitas Stomata } \\
\cline { 2 - 4 } & Normal & Normal & Abnormal \\
& Membuka & Menutup & \\
\hline Jalan Arif & 46,132 & 78,634 & 13,630 \\
Rahman & stomata/mm² & stomata/ & stomata/ \\
Hakim & & $\mathrm{mm}^{2}$ & $\mathrm{~mm}^{2}$ \\
\hline Taman & 32,502 & 65,004 & 13,630 \\
Benzena, & stomata/ & stomata/ & stomata/ \\
ITS & $\mathrm{mm}^{2}$ & $\mathrm{~mm}^{2}$ & $\mathrm{~mm}^{2}$ \\
\hline
\end{tabular}

Hasil menunjukan bahwa densitas stomata sampel daun pada Jalan Arief Rahman Hakim memiliki nilai46,132 stomata/mm²terbuka, lebih tinggi densitasnya dibandingkan dengan densitas stomata terbuka pada Taman Benzena, ITS yaitu 32,502 stomata/mm². Densitas stomata sampel daun pada Jalan Arief Rahman Hakim memiliki densitas 78,634 stomata/ $\mathrm{mm}^{2}$ tertutup, lebih besar dibandingkan dengan densistas stomata tertutup di Taman Benzena, ITS sebesar 65,004 stomata/ $\mathrm{mm}^{2}$, namun memiliki densitas stomata abnormal yang sama besar yaitu 13,630 stomata/mm².

Besaran densitas stomata dipengaruhi oleh paparan polutan yang berada di lingkungan. Nilai densitas stomata menutup yang lebih tinggi pada sampel daun di Jalan Arif Rahman Hakim dapat dikarenakan polusi udara berupa gas buangan dan timbal $(\mathrm{Pb})$ dari pembakaran tidak sempurna kendaraan bermotor di sekitar lokasi. Hal ini sesuai dengan pernyataan Raharjo, dkk, 2015 bahwa polusi dari sisa kendaraan bermotor seperti timbal akan terakumulasi pada bukaan stomata daun sehingga mempengaruhi metabolisme tanaman juga densitas pembukaan dan penutupan stomata. Stomata daun yang mengalami paparan polusi lebih banyak atau lebih lama akan tertutup oleh timbal, debu, zat kimia lain sehingga menunjukan densitas stomata tertutup yang lebih tinggi dibandingkan dengan densitas stomata terbuka (Raharjo et al., 2015). Pendapat literatur tersebut juga memperkuat dugaan pada sampel daun pada wilayah Jalan Arif Rahman Hakim memiliki densitas stomata tertutup yang lebih banyak dibandingkan dengan densitas stomata tertutup pada Taman Benzena, ITS. Asep (2016) menyatakan bahwa pencemar gas Nitrogen Oksida (NOx), Sulfur Oksida (SOx), Karbon Monoksida (CO), hidrokarbon dan partikulat berupa asap, kabut, dan debu yang mengenai 
permukaan daun atau stomata terus menerus dapat mengakibatkan terbentuknya sel dengan bentuk yang abnormal (Mutaqin et al., 2016). Stomata abnormal yang ditemukan pada kedua daun memiliki bentuk yang berbeda-beda. Pada pengamatan terlihat adanya sel tetangga dengan bentuk yang tidak sama besar, sel tetangga berkerut, ukuran sel apertur (penjaga) yang tidak sama besar, inti sel dengan ukuran yang lebih besar dari sel normal dan mulut daun yang terhalang oleh partikel berwarna hitam walaupun dalam kondisi stomata terbuka. Meskipun demikian kelainan struktural pada stomata tidak berpengaruh pada deferensiasi dari sel penjaga (Presell et al, 2014). Namun, tidak menutup kemungkinan jika sumber polusi yang mempengaruhi densitas dan morfologi stomata berasal dari sumber lain selain hasil pembakaran kendaraan bermotor.

Pada hasil penelitian didapatkan bahwa kedua lokasi memilki densitas stomata tertutup yang lebih besar dibandingkan dengan stomata terbuka. Selain karena paparan polusi, intensitas paparan sinar matahari dan naungan atau luasan yang menutupi permukaan daun juga mempengaruhi densitas stomata terbuka atau tertutup. Hal ini dapat dikarenakan paparan sinar matahari yang masih dalam waktu singkat mengingat pengambilan sampel dilakukan pada pagi hari dimana paparan sinar matahari belum terlalu intens. Permukaan daun yang terkena paparan sinar matahari lebih banyak akan memiliki densitas stomata yang lebih tinggi dibandingkan dengan permukaan daun yang ternaungi (Sihotang, 2017). Densitas stomata tertutup juga dapat dikarenakan hilangnya turgiditas sel karena keluarnya $\mathrm{K}^{+}$yang menyebabkan membukanya apertur stomata selain karena intensitas cahaya dan polusi di lingkungan

\section{KESIMPULAN DAN SARAN}

\section{Kesimpulan}

Berdasarkan hasil penelitian yang telah dilakukan didapatkan hasil berupa bentuk parasitik pada stomata daun Pterocarpus indicus pada kedua lokasi. Morfologi stomata normal membuka dan abnormal pada sampel daun pada Jalan Arif Rahman Hakim, sedangkan morfologi stomata normal membuka, normal menutup dan abnormal pada sampel daun Taman Benzena, ITS. Densitas stomata terbuka dan tertutup yang lebih besar pada sampel daun Pterocarpus indicus dari Jalan Arif Rahman Hakim dibandingkan dengan sampel daun pada Taman Benzena, ITS, serta memiliki stomata dengan morfologi abnormal karena adanya paparan polusi dari kendaraan bermotor atau perbedaan intensitas paparan cahaya matahari.

\section{DAFTAR PUSTAKA}

Danarto, S. A. (2013). Sebaran Anakan Angsana (Pterocarpus Indicus Wild.) Di Kebun Raya Purwodadi-Lipi. Proceeding Biology Education Conference: Biology, Science, Enviromental, and Learning, 10, 469-472. https://www.neliti.com/publications/17560 7/sebaran-anakan-angsana-pterocarpusindicus-wild-di-kebun-raya-purwodadi-lipi

Daszkowska-Golec, A., \& Szarejko, I. (2013). Open or close the gate - Stomata action under the control of phytohormones in drought stress conditions. Frontiers in Plant Science, 4(MAY), 1-17. https://doi.org/10.3389/fpls.2013.00138

Delnavaz Hashemloian, B. (2014). Abnormal and Cytoplasmic Connection of Guard Cells of Stomata of Leafs of Six Species of the Monocots. Journal of Plant Sciences (Science Publishing Group), 2(6), 334. https://doi.org/10.11648/j.jps.20140206.21

Haryanti, S. (2010). Jumlah dan Distribusi Stomata pada Daun Beberapa Spesies Tanaman Dikotil dan Monokotil. Anatomi Fisiologi, 18(2), 21-28. https://doi.org/10.14710/baf.v18i2.2600

Haryanti, S., \& Meirina, T. (2009). Optimalisasi Pembukaan Porus Stomata Daun Kedelai (Glycine max (L) merril) pada Pagi Hari dan Sore. Jurnal Bioma, 11(1), 18-23. https://doi.org/10.14710/bioma.11.1.11-16

Ingeswari, N. A. (2016). Karakteristik Stomata Daun Angsana (Pterocarpus indicus Will) Berdasarkan Ketinggian Tempat Yang Berbeda Seabagi Bahan Ajar Biologi [University of Muhammadiyah Malang]. http://eprints.umm.ac.id/id/eprint/45414

Kim, G. T., Yano, S., Kozuka, T., \& Tsukaya, H. (2014). Photomorphogenesis of leaves: Shade-avoidance and differentiation of sun 
and shade leaves. Photochemical and Photobiological Sciences, 4(7), 770-774. https://doi.org/10.1039/b418440h

Lestari, E. G. (2006). The relation between stomata index and drought resistant at rice somaclones of Gajahmungkur, Towuti, and IR 64. Biodiversitas, Journal of Biological Diversity, 7(1), 44-48. https://doi.org/10.13057/biodiv/d070112

Mansfield, T. A. (1998). Stomata and plant water relations: Does air pollution create problems? Environmental Pollution, 101(1), 1-11. https://doi.org/10.1016/S02697491(98)00076-1

Mutaqin, A. Z., Budiono, R., Setiawati, T., Nurzaman, M., \& Fauzia, R. S. (2016). Studi Anatomi Stomata Daun Mangga (Mangifera indica) Berdasarkan Perbedaan Lingkungan. Jurnal Biodjati, 1(1), 13-18. https://doi.org/10.15575/biodjati.v1i1.1009

Paembonan, S. A. (2002). Aspek Ekofisiologi dalam Pengelolaan dan Pelestarian Eboni (Diospyros celebica Bakh.). Berita Biologi, 6(2), 363-366.

Pearcy, R. ., Ehleringer, J. ., Mooney, H. ., \& Rundel, P. . (1989). Plant Physiological Ecology: Field Metdhods and Instrumentation. Kluwer Academic Publisher. https://doi.org/10.1007/978-94010-9013-1

Pressel, S., Goral, T., \& Duckett, J. G. (2014). Stomatal differentiation and abnormal stomata in hornworts. Journal of Bryology, 36(2), 87-103. https://doi.org/10.1179/1743282014Y.0000 000103
Raharjo, H. P., Haryanti, S., \& Budihastuti, R. (2015). Pengaruh Tingkat Kepadatan Lalu Lintas dan Waktu Pengamatan yang Berbeda Terhadap Ukuran dan Jumlah Stomata Daun Glodokan (Polyalthia longifolia .Sonn). Jurnal Biologi Universitas Andalas (J. Bio. UA.), 4(1), 73-84. https://doi.org/10.1017/CBO97811074153 24.004

Rindyastuti, R., \& Hapsari, L. (2017). Adaptasi Ekofisiologi Terhadap Iklim Tropis Kering: Studi Anatomi Daun Sepuluh Jenis Tumbuhan Berkayu ( Ecophysiological adaptation to dry tropical climate: a study of foliar anatomic structure of ten woody plant species ). Jurnal Biologi Indonesia, 13(1), 1-14.

Sihotang, L. (2017). Analisis Densitas Stomata Tanaman Antanan (Centella asiatica , L) Dengan Perbedaan Intensitas Cahaya. Jurnal Pro-Life, 4(2), 329-338.

Wu, S., \& Zhao, B. (2017). Using Clear Nail Polish to Make Arabidopsis Epidermal Imperssions for Measuring the Change of Stomatal Aperture Size in Immune Response. In Methods in Molecular biology (Vol. 1578, Issue February, pp. 5-8). https://doi.org/10.1007/978-1-4939-68596

Yudha, G. P., Noli, Z. A., \& Idris, D. M. (2013). Pertumbuhan Daun Angsana (Pterocarpus indicus Willd) dan Akumulasi Logam Timbal $(\mathrm{Pb})$ The leaves growth of angsana (Pterocarpusindicus Willd) and lead (Pb) accumulation. Jurnal Biologi Universitas Andalas (J. Bio. UA.), 2(2), 83-89. 